\title{
P-wave velocity structure of the southern Ryukyu margin east of Taiwan: Results from the ACTS wide-angle seismic experiment
}

\author{
Klingelhoefer Frauke ${ }^{1,{ }^{*}}$, Berthet T. ${ }^{2}$, Lallemand S. ${ }^{2}$, Schnurle Philippe ${ }^{1}$, Lee C. - S. ${ }^{3}$, Liu C. $-\mathrm{S} .{ }^{4}$, \\ Mcintosh K., Theunissen T. ${ }^{2}$
}

${ }^{1}$ IFREMER, Dep Marine Geosci, Ctr Brest, F-29280 Plouzane, France.

2 Univ Montpellier 2, CNRS, Geosci Montpellier, F-34095 Montpellier 5, France.

${ }^{3}$ NTOU, Dept Geophys, Keelung, Taiwan.

${ }^{4}$ NTU, Inst Oceanog, Taipei, Taiwan.

*Corresponding author : Frauke Klingelhoefer, email address : fklingel@ifremer.fr

\begin{abstract}
:
An active seismic experiment has been conducted across the southern Ryukyu margin east of Taiwan over the whole trench-arc-backarc system in May 2009. Twenty-four ocean bottom seismometers (OBS) were deployed from the Ryukyu trench to the southern Okinawa trough over the Ryukyu arc and forearc. Wide angle seismic data were recorded by the OBS array while coincident reflection seismic data were acquired using a $6 \mathrm{~km}$ long streamer and a 6600 cubic inch seismic airgun array. Results from tomographic inversion of 21091 travel time picks along this line allowed us to image crustal structures of the Ryukyu margin down to a depth of $25 \mathrm{~km}$. The transect has been designed to provide a better seismic velocity structure of the subduction zone in a highly deformed area that has produced an M8 earthquake in 1920. The line crosses a seismic cluster of earthquakes which source mechanisms are still poorly understood. The subducting oceanic crust of the Huatung Basin is about 5-6 km thick. The underlying mantle exhibits low seismic velocities around $7.8 \mathrm{~km} / \mathrm{s}$ suggesting some hydrothermal alterations or alteration of the upper mantle through faults generated by the flexure of the subducting plate as it enters the subduction. Low velocities, up to $4.5 \mathrm{~km} / \mathrm{s}$, associated with the accretionary wedge are well imaged from the trench back to the Nanao forearc. A major result concerns the abrupt termination of the buttress at the rear of the accretionary wedge. Despite the low resolution of the tomographic inversion near the subduction interface, several lines of evidence supporting the presence of a low velocity zone beneath the toe of the forearc buttress could be established. The Moho beneath the Ryukyu non-volcanic arc is located at a depth around $25 \mathrm{~km}$ depth. (C) 2011 Elsevier B.V. All rights reserved.
\end{abstract}




\section{Highlights}

- This paper presents new deep seismic data from a profile across the southern Ryukyu margin east of Taiwan. Results from tomographic inversion allows to image crustal structures of the Ryukyu margin down to a depth of $25 \mathrm{~km}$. The subducting oceanic crust is about 5-6 km thick and the underlying mantle exhibits relatively low seismic velocities. The buttress of the accretionary wedge ends abruptly and some evidence supports a low velocity zone at the forearc. The Moho beneath the Ryukyu nonvolcanic arc is located at a depth around $25 \mathrm{~km}$ depth.

Keywords : Ryukyu Trench, Marine seismics, Wide-angle seismics, Subduction processes 


\section{Introduction and previous work}

${ }_{41}$ similar geometrical and tectonic characteristics than the Andaman subduction zone that

${ }_{42}$ underwent a giant $\mathrm{Mw} 9.2$ event in 2004. One of the main aims of this work is thus to

${ }_{43}$ better image the crustal structure in this area in order to better constrain the source of

a4 the seismicity.

${ }_{45}$ One of the first wide-angle seismic surveys conducted south of Taiwan constrained the

${ }_{46}$ nature of the crust in the South China Sea Basin to be oceanic and bounded to the north ${ }_{47}$ and south by continental type crust [Ludwig et al., 1979]. From modelling of three wide- 
$\mathrm{X}-4$

${ }_{48}$ angle seismic lines, Murauchi et al. [1968] deduced, that the crust underlying the Okinawa

49 Trough is generally similar to that of continental crust, with a Moho depth of $12 \mathrm{~km}$ in the

so eastern Okinawa Trough thinning towards the northwest. Leyden et al. [1973] correlated

${ }_{51}$ offshore refraction velocities with onland drilling and refraction data to propose a crustal

52 structure in the Okinawa Trough. Based on models from wide-angle seismic data, Hagen

${ }_{53}$ et al. [1988] propose the nature of the crust east of Taiwan and south of the Ryukyu

${ }_{54}$ Trench to be oceanic and continental north of the trench. Lee et al. [1980] using two ship

${ }_{55}$ seismic refraction lines, found that the Okinawa trough is underlain by a roughly $9 \mathrm{~km}$

${ }_{56}$ thick crust, which is overlain by an acoustic basement layer and a 1-2 km thick layer of

57 sediments.

58 In 1995 a large scale land-sea wide-angle seismic experiment was carried out east and

s9 south of Taiwan using the $\mathrm{R} / \mathrm{V}$ Maurice Ewing for reflection seismic data acquisition

${ }_{60}$ and the $\mathrm{R} / \mathrm{V}$ Ocean Researcher 1 for deployment and recovery of the instruments [Yeh

${ }_{61}$ et al., 1998]. One of these regional profiles, oriented north-south, spans from the Okinawa

${ }_{62}$ Trough over the Ryukyu Arc and onto the Philippine Sea Plate (Figure 1) [Wang et al.,

${ }_{63}$ 2001, 2004]. This profile (line 1), which is located in our study area, but oriented in a

${ }_{64}$ different angle, images a sudden increase in subduction angle of the PSP below the Nanao

${ }_{65}$ forearc basin. Moho depth at the Ryukyu Arc is around $30 \mathrm{~km}$, and around $13 \mathrm{~km}$ at the

${ }_{66}$ PSP. Three profiles oriented roughly east-west (Lines 14, 16 and 23) were each extended on

${ }_{67}$ land. Preliminary modelling of southern Line 23 covering the Luzon Arc shows thickening

${ }_{68}$ of the PSP towards the EP, but no indications of a westward subduction of the PSP

${ }_{69}[$ Hetland and Wu, 1998; Yang and Wang, 1998] as previously proposed by Chemenda

7o et al. [1997]. Line 14 crosses our profile in the forearc area and is located roughly parallel 
${ }_{71}$ to the Ryukyu Arc. Modelling of the OBS data along this profile indicates a poorly

72 constrained Moho depth near $30 \mathrm{~km}$ in the vicinity of our profile leading to a crustal

${ }_{73}$ thickness larger than $25 \mathrm{~km}$. Sedimentary layers thicken in the Nanao and East Nanao

${ }_{74}$ Basin and the continental basement of the Ryukyu arc has been interpreted to terminates

${ }_{75}$ beneath the accretionary wedge at a distance of $60 \mathrm{~km}$ from the trench [McIntosh and

${ }_{76}$ Nakamura, 1998; Wang et al., 2001]. However, McIntosh et al. [2005], demonstrated that

${ }_{77}$ thickened crust was limited to the extinct North Luzon Arc. East of this, at the base

78 of the slope, the OBS data require normal to slightly thin oceanic crust. They found no

79 evidence of significant deformation east of the arc. Line 16, sub-parallel to Line 14 in the

so forearc (see Figure 1) images the top of the subducting PSP at depths between 20 and 25

${ }_{81} \mathrm{~km}$ [Wang and Chiang, 1998; McIntosh et al., 2005].

82 An active seismic cluster has been imaged in the forearc area using relocations of 1139

sз events recorded on both taiwanese and japanese landstations from 1992 and 1997 in a

${ }_{84}$ 3D velocity model [Font et al., 2003; Font and Lallemand, 2009]. These clustered events

${ }_{85}$ mainly align with geomorphological features such as the Hoping canyon at the surface or

${ }_{86}$ the Hoping basement rise in depth. Even if a few of them locate onto the subduction

${ }_{\text {s7 }}$ interface, most of them occur within the upper plate, often at shallow depths. Focal

s8 mechanisms within the shallow group indicate either a high-angle backthrust dipping south

s9 or a north dipping low-angle thrust [Font et al., 2003; Font and Lallemand, 2009]. Together

so with additional data the authors propose the existence of an active splay fault, probably

${ }_{91}$ resulting from the subduction of an oceanic relief and causing the abnormal seismic activity

$92 \quad$ [Font and Lallemand, 2009]. Such splay faults, connected onto the subduction plate

${ }_{93}$ interface, are able to generate a mega-thrust earthquake such as those known in Nankai 
${ }_{94}$ or Sumatra. At the same time, the authors were puzzled by both the shallowness of

95 most events and the fact that no surface evidence of splay fault emergence was observed.

96 They thus questionned the accuracy of earthquake location with a large azimuthal gap

${ }_{97}$ in land stations with respect to the offshore events. In order to better constrain the

98 seismic activity in this highly deformed region, two seismic experiments were conducted:

99 one active during which a combined wide-angle and reflection seismic profile was acquired

\section{OBS data acquisition and preprocessing}

102 


\section{Multichannel seismic data processing}


$X-8$

${ }_{138}$ at sea bottom to $2-16-32-48 \mathrm{~Hz} 3 \mathrm{~s}$ below), inside and out-side mute, stack, and post-

${ }_{139}$ stack time variant band-pass filter and Kirchhoff time migration. Two pass of semblance

${ }_{140}$ velocity analysis (at 500 then $250 \mathrm{cdp}$ ) were performed on 8 cdp super-gathers (full fold

${ }_{141}$ of 468 channels), using the velocities of the tomographic inversion of the OBS records as

${ }_{142}$ guide function in order to constrain stacking velocities at depth where semblance is poor.

${ }_{143}$ Multiple attenuation was achieved with an FK-filter applied to super-gathers of 4 cdps

${ }_{144}$ (half fold at $25 \mathrm{~m}$ trace interval). Moreover, an additional radon velocity filter (from 25

${ }_{145} \%$ below to $50 \%$ above) was applied to the south-western portion of the profile in order

${ }_{146}$ to further attenuate multiples that compromise seismic imaging of the subducting PSP

${ }_{147}$ underneath the accretionary prism. However in this area, structures are poorly imaged:

${ }_{148}$ rough topography, little continuity in the reflectors, and steep dips result in high noise

${ }_{149}$ and short lived features on the seismic profile.

\section{Tomographic inversion}

${ }_{150}$ The tomographic inversion code FAST [Zelt and Barton, 1998] was further used to

151 


\section{Forward ray-tracing modelling}


X - 10

\section{Error analysis} seismic rays.

constrained by synthetic seismogram modelling using the finite-difference modelling code from the Seismic Unix package [Cohen and Stockwell, 2003; Stockwell, 1999].

The final model comprises 7 layers: the water layer, two sedimentary layers, an oceanic crustal layer, two arc crustal layers and the upper mantle layer (Figure 5). Each layer is defined by depth and velocity nodes. Water velocity is a constant $1.5 \mathrm{~km} / \mathrm{s}$ throughout the model. The seafloor model layer includes depth nodes at a spacing of $1 \mathrm{~km}$ and sedimentary layers at a spacing of $2.5 \mathrm{~km}$. A node spacing at the deeper crustal layers of $5 \mathrm{~km}$ seemed adequate. The velocities of the two sedimentary layers range from $2.0-2.2$ $\mathrm{km} / \mathrm{s}$ and $3.5-4.5 \mathrm{~km} / \mathrm{s}$ in the deeper part of the accretionary prism. Velocities in the Ryukyu arc are $4.5-5.5 \mathrm{~km} / \mathrm{s}$ for the upper layer and $5.5-7.0 \mathrm{~km} / \mathrm{s}$ for the lower layer. The limit between these two layers is not constrained by reflected waves but is required to have two different velocity gradients and allow to obtain a better fit of the refracted waves within the arc crust. Mantle velocities are constrained from $7.8-8.2 \mathrm{~km} / \mathrm{s}$ in the oceanic domain, however in the arc region the mantle velocities are not sampled by the

In order to constrain the dependency of the final tomographic model of on the initial model, different model runs were conducted using different initial models. A variety of simple initial models where constructed and the inversion performed (Figure 6). The resulting models are characterized by an equal or lower fit of the data. Models calculated from a horizontal Moho or a Moho dipping towards the northeast lead to nearly identical results (Figures 6 A, B, C, and D). Model using an unrealistic deep Moho at the SW end 
X -12 
${ }^{249}$ by Wang et al. [2001] with less dense OBS network on the seafloor. In this case, the 250 phases reflected from the continental crust arrive too early and some refracted waves does ${ }_{251}$ not fit the data well. Thus, the resulting model is characterised by a higher RMS error ${ }^{252}$ and a lower percentage of picks which could be successfully reached by rays than in the ${ }_{253}$ final velocity model. Secondly, as the inverse model shows a very steep inclination of the ${ }^{254}$ isovelocity contours in this region, a near-vertical position of the backstop, as already ${ }_{255}$ proposed by Font et al. [2001], was tested. Although the rms-error is as high as in the ${ }_{256}$ previous model, the trend of the refracted waves passing through the backstop and those ${ }^{257}$ of the reflected waves on the sides better fit the picked arrivals. Thus, our data support ${ }_{258}$ the existence of a sharp backstop. Refinement of this model resulted in our final velocity 259 model which is characterised by an abrupt nearly vertical backstop including low velocities ${ }_{260}$ at the front end of the backstop. The rms-error of this model is $142 \mathrm{~ms}$ and $95 \%$ of the ${ }_{261}$ picks can be explained. 
$\mathrm{X}-14$

\section{Comparison with reflection seismic data} ${ }_{278}$ boundary.

\section{Results and discussion}


${ }_{283}$ Profile in the Okinawa Trough. Klingelhoefer et al. [2005] suggest that the high velocity

${ }_{284}$ contrast found between the sedimentary layers and the accoustic basement might be due

285 to the inclusion of some backarc volcanism or arc relics emplaced during formation of older

${ }_{286}$ backarc basins since early Tertiary. The sedimentary layer overlying the Huatung Basin 
$\mathrm{X}-16$ 
X - 18

\section{Conclusions}

Velocity modelling of wide-angle seismic data of a profile located over the whole trencharc-backarc system, from the Ryukyu trench to the Okinawa back-arc trough allows to image the subducting slab down to a depth of up to $25 \mathrm{~km}$. Based on this velocity model we propose that :

1) The sedimentary thickness on the oceanic plate is about $2-3 \mathrm{~km}$,

2) The thickness of the oceanic crust is about $5-6 \mathrm{~km}$, slightly thinner than normal oceanic crust,

3) Both the tomographic inversion of first arrivals and the forward model reveal a backstop characterised by a very steep inclination. Although this region of the model is not highly constrained and no reflections from the backstop can be identified in multichannel seismic data, it produces the lowest error of several geometries tested. Low velocities are observed at the base of the backstop in the tomographic inversion and are confirmed by forward modeling. This could be the sign of active tectonic erosion,

4) Our forward model indicates a deflection of the subducting PSP beneath the forearc buttress that may reveal compression and/or overloading,

5) The upper mantle material underlying the oceanic plate is characterised by relatively low seismic velocities which might be due to the partial serpentinisation of the mantle peridotites by water passing through faults in the oceanic plate. The faults might be generated by the bending of the subducting plate before subducting, but also by an early fabric.

\section{Acknowledgments.}




\section{References}

379 of this paper.

We would like to thank all colleagues from the TAIGER project who made it possible o acquire this profile during their experiment. We also would like to thank the captain and the crew of the $\mathrm{R} / \mathrm{V}$ Yun-Ying 2 and the $\mathrm{R} / \mathrm{V}$ Marcus Langseth. Acquisition and

processing of the data were funded by the Agence Nationale de la Recherche and Ifremer.

Many thanks to Anne Delplanque for help with the figures. The GMT [Wessel and Smith, 1995] and Seismic Unix software package [Stockwell, 1999] were used in the preparation

Auffret, Y., P. Pelleau, F. Klingelhoefer, L. Gïæjli, J. Crozon, J.-Y. Lin, and J.-C. Sibuet, Microbs : a new generation of bottom seismometer., First Break, pp. 41-47, 2004.

Chemenda, A., R. K. Yang, C. H. Hsieh, and A. Groholski, Evolutionary model for the taiwan collision based on physical modeling, Tectonophysics, 274, pp. 253-274, 1997.

Chen, R. Y., H. Kao, W. T. Liang, T. C. Shin, Y. B. Tsai, and B. S. Huang, Threedimesional pattern of seismic deformation in the taiwan region with special implication from the 1999 chi-chi earthquake sequence, Tectonophysics, 446, pp. 140-151, 2009.

Cohen, J. K., and J. W. Stockwell, Seismic Unix Release 37: a free package for seismic research and processing, Center for Wave Phenomena, Colorado School of Mines., 2003.

Contreras-Reyes, E., E. R. Flueh, and I. Grevemeyer, Tectonic control on sediment accretion and subduction off central chile : Implications for coseismic rupture processes of the 1960 and 2010 megathrust earthquakes, Tectonics, 29, TC6018, doi :10.1029/2010TC002734, 2010.

Deschamps, A., S. Lallemand, and J. Y. Collot, A detailed study of the Gagua Ridge: A fracture zone uplifted during a plate reorganisation in the Mid-Eocene, Marine 
$\mathrm{X}-20$

394 Geophys. Research, 20, 403-423, 1998.

395 Font, Y., and S. Lallemand, Subducting oceanic high causes compressional faulting in 396 southernmost Ryukyu forearc as revealed by hypocentral determinations of earthquakes ${ }_{397}$ and reflection/refraction seismic data, Tectonophysics, 466 (3-4), pp. 255-267, 2009.

${ }_{398}$ Font, Y., S.-C. Liu, P. SchnÃijrle, and S. Lallemand, Constraints on backstop geometry from the southwest Ryukyu subduction based on reflection seismic data, Tectonophysics, 333, 135-158, 2001.

Font, Y., H. Kao, C.-S. Liu, and L.-Y. Chiao, A comprehensive 3D seismic velocity model ${ }_{402}$ for the eastern Taiwan-southernmost Ryukyu regions, Terr. Atm. Oc. Sci., 14, pp. 159-182, 2003. 363-378, 1998.

${ }^{414}$ Hsu, S.-K., and J.-C. Sibuet, Earthquake off japan could generate strong tsunami, EOS, ${ }_{415} \quad 86(17)$, pp. $169-170,2005$. 
${ }_{416}$ Klingelhoefer, F., R. A. Edwards, R. W. Hobbs, and R. W. England, Crustal structure ${ }_{417}$ of the NE-Rockall Trough from wide-angle seismic data modelling, J. Geophys. Res., ${ }_{418} \quad 110$, p. B11105, 2005.

${ }_{419}$ Klingelhoefer, F., M.-A. Gutscher, S. Ladage, J.-X. Dessa, D. Graindorge, D. F. C. Andre,

H. Permana, T. Yudistira, and A. Chauhan, The limits of the seismogenic zone in the epicentral region of the 26 dec. 2004 great Sumatra-Andaman earthquake: results from a seismic refraction and wide-angle reflection surveys and thermal modeling, J. Geophys. Res. 115, B01304, doi:10.1029/2009JB006569, 2010, pp. 1-23, 2010.

Kuo-Chen, H., F. T. Wu, Y. Nakamura, C. Lee, and K. MacIntosh, Relocation of earthquakes and tectonics of offshore Taiwan with the addition of TAIGER BBOBS, Eos, Transactions, American Geophysical Union, 89 (53), pp. T31C-2023, 2008.

Langston, C. A., W. H. K. Lee, C.-J. Lin, and C.-C. Liu, Seismic-wave strain, rotation, and gradiometry for the 4 march 2008 taiger explosions, Bull. Seis. Soc. Am., 99 (2B), pp. 1287-1301, 2009.

Lee, C.-S., G. G. Shor, L. D. Bibee, R. S. Lu, and T. W. C. Hilde, Okinawa Trough: Origin as backarc basin, Mar. Geology, 35, pp. 219-241, 1980.

Lester, W. R., K. McIntosh, and H. van Avendonk, Seismic velocity structure of the Eurasian Continental Margin in the Northern South China Sea from wide-angle obs data, Proceedings from the 2010 AGU Western Pacific Geophysics Meeting, pp. 22-25, 2010.

Leyden, R., M. Ewing, and S. Murauchi, Sonobuoy refraction measurements in East China Sea, Am. Assoc. Pet. Geol. Bull. 57 (12), pp. 2396-2403, 1973. 
$\mathrm{X}-22$

${ }^{438}$ Louden, K., The crustal and lithospheric thicknesses of the Philippine Sea as compared ${ }_{439}$ to the Pacific, Earth Planet. Sci. Lett., 50, pp. 275-288, 1980.

${ }_{440}$ Ludwig, W. J., N. Kumar, and R. E. Houtz, Profiler-sonobuoy measurements in the South

${ }_{441} \quad$ China Sea Basin, J. Geophys. Res., 84(B7), pp. 3505-3518, 1979.

${ }_{442}$ McIntosh, K., and Y. Nakamura, Crustal structure beneath the nanao Forearc Basin from ${ }_{443}$ TAICRUST MCS/OBS Line 14, TAO, 9, pp. 345-362, 1998.

${ }_{444}$ McIntosh, K., Y. Nakamura, T.-K. Wang, R.-C. Shih, A. Chen, and C.-S. Liu, Crustal${ }_{445}$ scale seismic profiles across Taiwan and the western Pilippine Sea, Tectonophys., 401, ${ }_{446} \quad$ pp. $23-54,2005$.

${ }_{447}$ Murauchi, S., N. Den, S. Asano, H. Hotta, T. Yoshii, T. Asanuma, K. Hagiwara, ${ }_{448}$ K. Ichikawa, T. Sato, W. J. Ludwig, J. I. Ewing, N. T. Edgar, and R. E. Houtz, 449 Crustal structure of the Philippine Sea, J. Geophys. Res., 73, pp. 3143-3171, 1968.

${ }_{450}$ Ranero, C. R., J. P. Morgan, K. McIntosh, and C. Reichert, Bending-related faulting and ${ }_{451}$ mantle serpentinization at the Middle America Trench, Nature, pp. 367-373, 2003.

${ }_{452}$ Seno, T., S. Stein, and A. Gripp, A model for the motion of the philippine sea plate ${ }_{453}$ consistent with NUVEL-1 and geological data, J. Geophys. Research, 98, 17,941-17,948, $454 \quad 1993$.

${ }_{455}$ Stockwell, J. W., The cwp/su: Seismic un*x package, Computers and Geosciences, 1999.

${ }_{456}$ Theunissen, T., Y. Font, S.Lallemand, and W. T. Liang, The largest instrumentally ${ }^{457}$ recorded earthquake in Taiwan : revised location and magnitude, and tectonic sig${ }_{458}$ nificance of the 1920 event, Geophys. J. Int., doi: 10.1111/j.1365-246X.2010.04813.x, 183, 1119-1133, 2010. 
474

Wang, T. K., and C.-H. Chiang, Imaging of arc-arc collision in the Ryukyu forearc region offshore hualien from TAICRUST OBS Line 16, TAO, 3, pp. 329-344, 1998.

Wang, T. K., K. Mcintosh, Y. Nakamura, C.-S. Liu, and H.-W. Chen, Velocity-interface structure of the southwestern Ryukyu subduction zone from EW9509-1 OBS/MCS data, Mar. Geophys. Res., 22, pp. 265-287, 2001.

Wang, T. K., S.-F. Lin, C.-S. Liu, and C.-S. Wang, Crustal structure of the southernmost Ryukyu subduction zone: OBS, MCS and gravity modelling, Geophys. J. Int., 157, pp. $147-163,2004$.

Wessel, P., and W. H. F. Smith, A new version of the Generic Mapping Tool (GMT), EOS, Trans. Am. Geophys. Un., 76, p. 329, 1995.

White, R. S., D. McKenzie, and R. O’Nions, Oceanic crustal thickness from seismic measurements and rare earth element inversions, J. Geophys. Res. 97, pp. 19,683-19,715, 1992.

Yang, Y.-S., and T. K. Wang, Crustal velocity variation of the Philippine Sea Plate from TAICRUST OBS/MCS Line 23, TAO. 9, pp. 379-393, 1998.

Yeh, Y. H., R. C. Shih, C. H. Lin, C. C. Liu, H. Y. Yen, B. S. Huang, C. S. Liu, P. Z. Chen, C. S. Huang, C. J. Wu, and F. T. Wu, Onshore/offshore wide-angle deep seismic profiling in Taiwan, TAO. 9, pp. 301-316, 1998.

Yu, S. B., H. Y. Chen, and L. Kuo, Velocity field of GPS stations in the Taiwan area, Tectonophysics 274(1-3), pp. 41-59, 1997.

Zelt, C., and P. Barton, Three-dimensional seismic refraction tomography : a comparison of two methods applied to data from the Faeroe Basin, J. Geophys. Research, 103, $7187-7210,1998$ 
$\mathrm{X}-24$

${ }_{483}$ Zelt, C. A., and R. B. Smith, Seismic travel time inversion for 2-d crustal velocity struc-

${ }_{484}$ ture, Geophys. J. Int. 108, pp. 16-31, 1992.

\section{Figure Captions}

485

486

487

488

489

490

491

492

493

494

495 
504 Figure 6: Results fromt the test of different starting models. (A) Starting model including

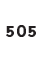

506

507 ${ }_{525}$ OBS.

(C) Starting model including a Moho dipping to the NE. (D) Resulting model after 5 iterations. (E) Starting model including a Moho dipping to the SW. (F) Resulting model after 5 iterations.

Figure 7: Results of the checkerboard test. (A) synthetic model including anomalies of the size $10 \mathrm{~km} \times 5 \mathrm{~km}$. (B) Resulting model after one iteration. (C) synthetic model including anomalies of the size $20 \mathrm{~km}$ x $10 \mathrm{~km}$. (D) Resulting model after one iteration.

(E) synthetic model including anomalies of the size $40 \mathrm{~km}$ x $15 \mathrm{~km}$. (F) Resulting model after one iteration.

Figure 8: (a) Bandpass filtered $(3-5 \mathrm{~Hz}, 24-36 \mathrm{~Hz})$ vertical geophone data section from OBS 17. The data are displayed with a gain proportional to source-receiver offset and are reduced at a velocity of $8 \mathrm{~km} / \mathrm{s}$. PmP (reflection from the Moho), and Pn (turning waves fromt he upper mantle) are annotated (b) Synthetic seismograms calculated from the velocity model for the same station using the finite-difference modelling code from the Seismic Unix package (Cohen, 2003; Stockwell, 1999). The synthetic seismograms are calculated every $100 \mathrm{~m}$ with a source frequency centred around $5 \mathrm{~Hz}$.

Figure 9: (a) Different geometries of the backstop. (a) model with a smoothly decling backstop (b) model with a steep backstop (c) final velocity model

Figure 10: Comparison of the velocity models with multi-channel seismic data. (A) MCS data underlain by the tomographic velocity model. Red dots mark position of the OBS. (B) MCS data underlain by the forward velocity model. Red dots mark position of the 
$\mathrm{X}-26$

${ }_{526}$ Figure 11: Interpreted geological cross section based on the forward and tomographic 527 velocity model.

528 Figure 12: Velocity-depth relationship for the oceanic crust at -50, -25, 025 and $50 \mathrm{~km}$ 529 model distance. Black lines are from the forward and dashed lines from the tomographic ${ }_{530}$ model. Grey-shaded area is from White et al. [1992] for normal oceanic crust.

${ }_{531}$ Figure 11: Bathymetry of the study area. Location of the Profiles RATS-3 and ${ }_{532}$ TAICRUST EW9509-1 are marked by black lines and position of the OBS by inverted ${ }_{533}$ triangles. 


\begin{tabular}{|c|c|c|c|c|}
\hline Phase & & No of picks & RMS traveltime residual & chi-squared \\
\hline Water & 1 & 1785 & 0.040 & 0.163 \\
\hline Sediments 1 & 2 & 107 & 0.101 & 1.040 \\
\hline Sediments 1 reflection & 3 & 378 & 0.131 & 1.721 \\
\hline Sediments 2 & 4 & 1708 & 0.182 & 3.303 \\
\hline Sediments 2 reflection & 5 & 1717 & 0.123 & 1.515 \\
\hline Arc upper crust & 6 & 3831 & 0.130 & 1.685 \\
\hline Arc Moho & 7 & 1873 & 0.182 & 3.296 \\
\hline Oceanic crust & 8 & 3187 & 0.155 & 2.402 \\
\hline Oceanic Moho & 9 & 320 & 0.150 & 2.258 \\
\hline Oceanic mantle & 11 & 2843 & 0.133 & 1.757 \\
\hline Arc lower crust & 12 & 7863 & 0.143 & 2.059 \\
\hline All Phases & & 25612 & 0.142 & 2.009 \\
\hline
\end{tabular}

Table 1. Traveltime residuals and chi squared error for all phases and the complete model. 


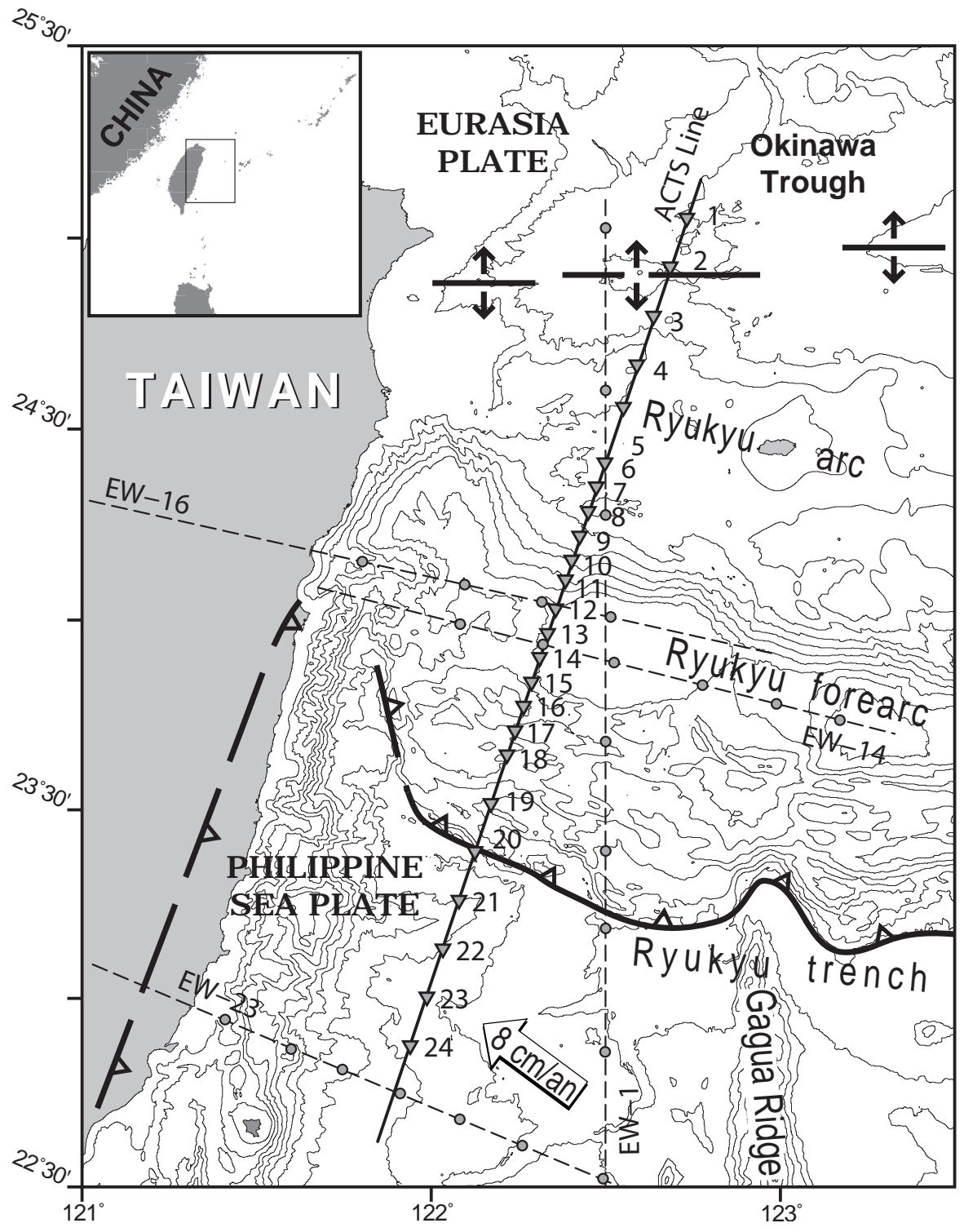

Figure 1. 

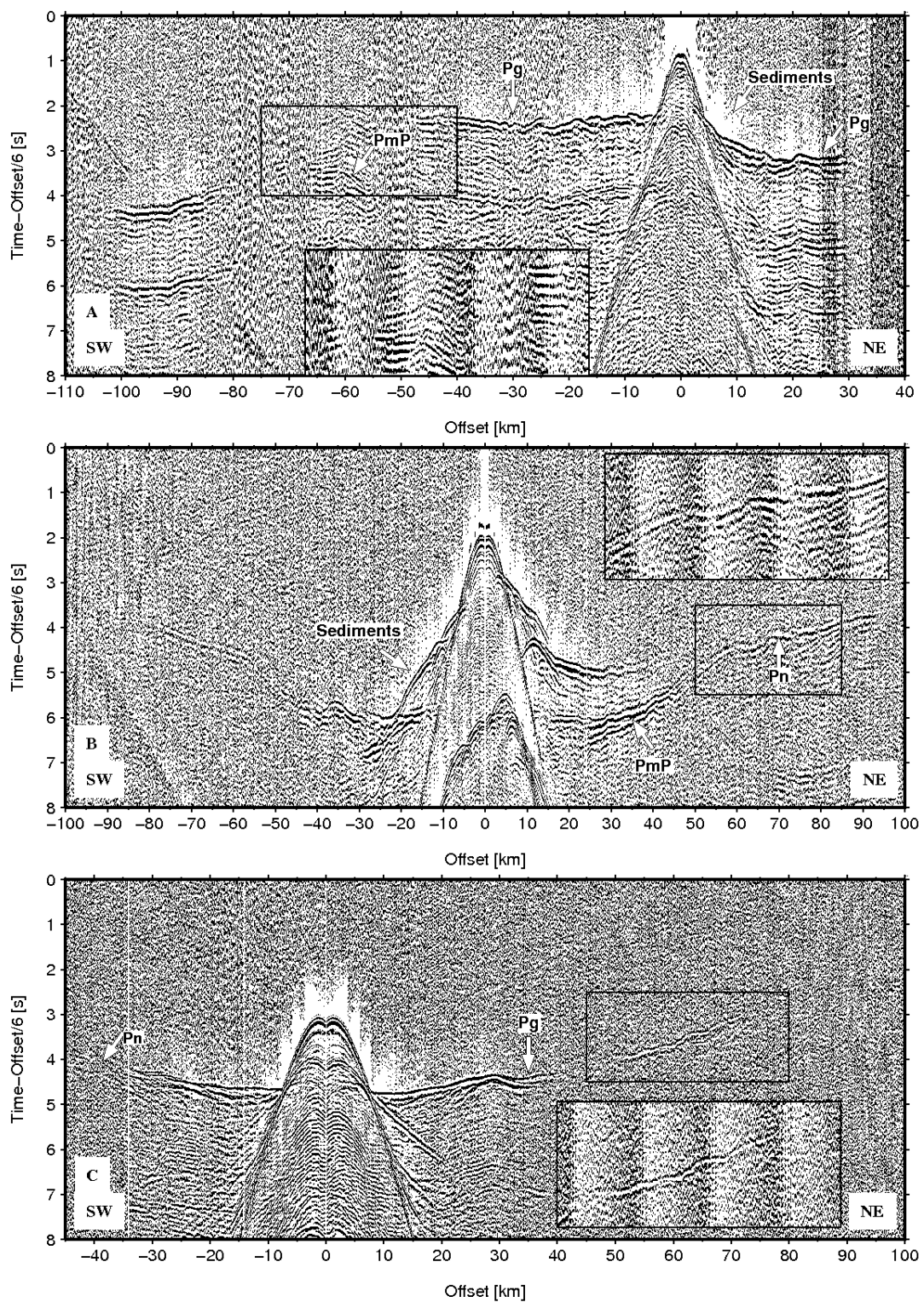

Figure 2. 


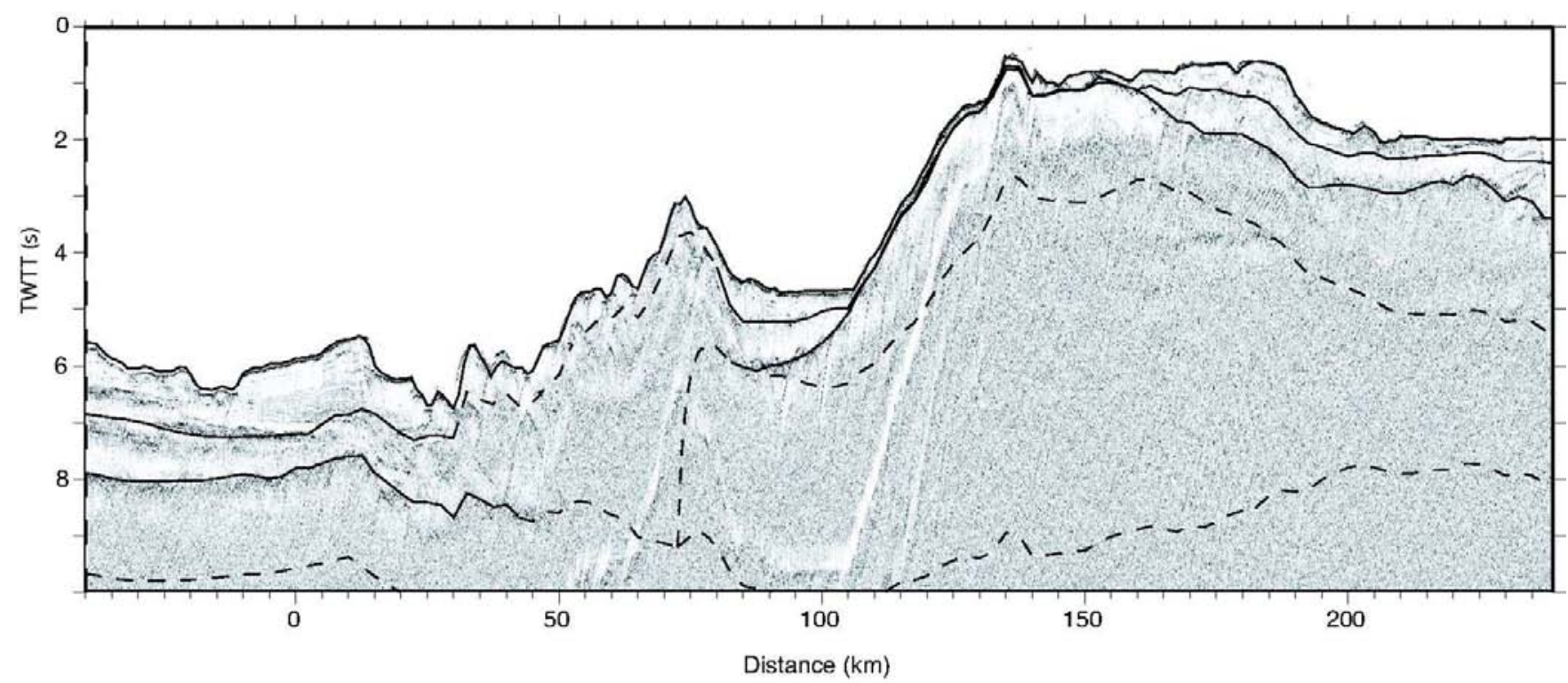




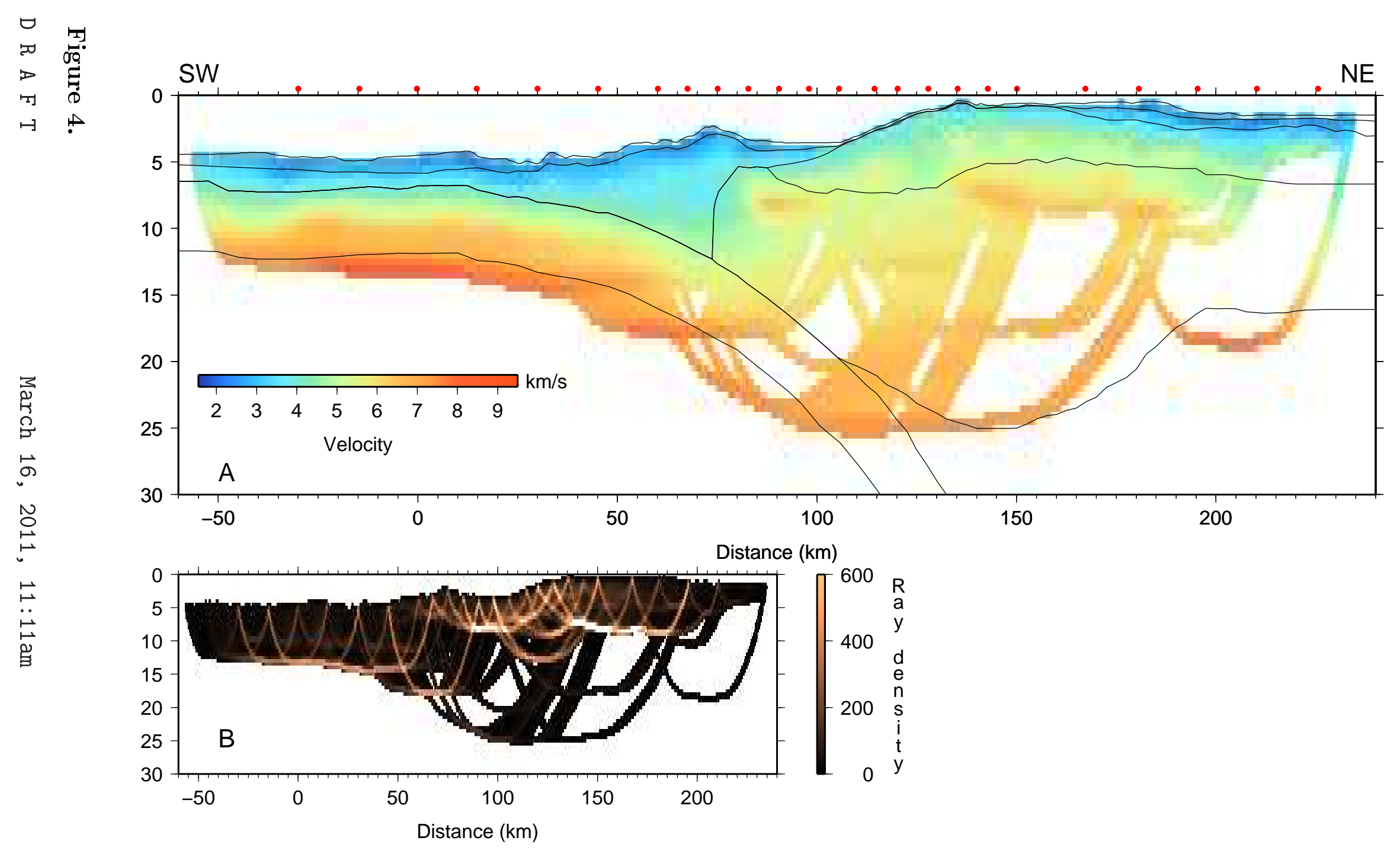

$\ominus$
$\square$
$D$
$\mapsto$
$\mapsto$ 

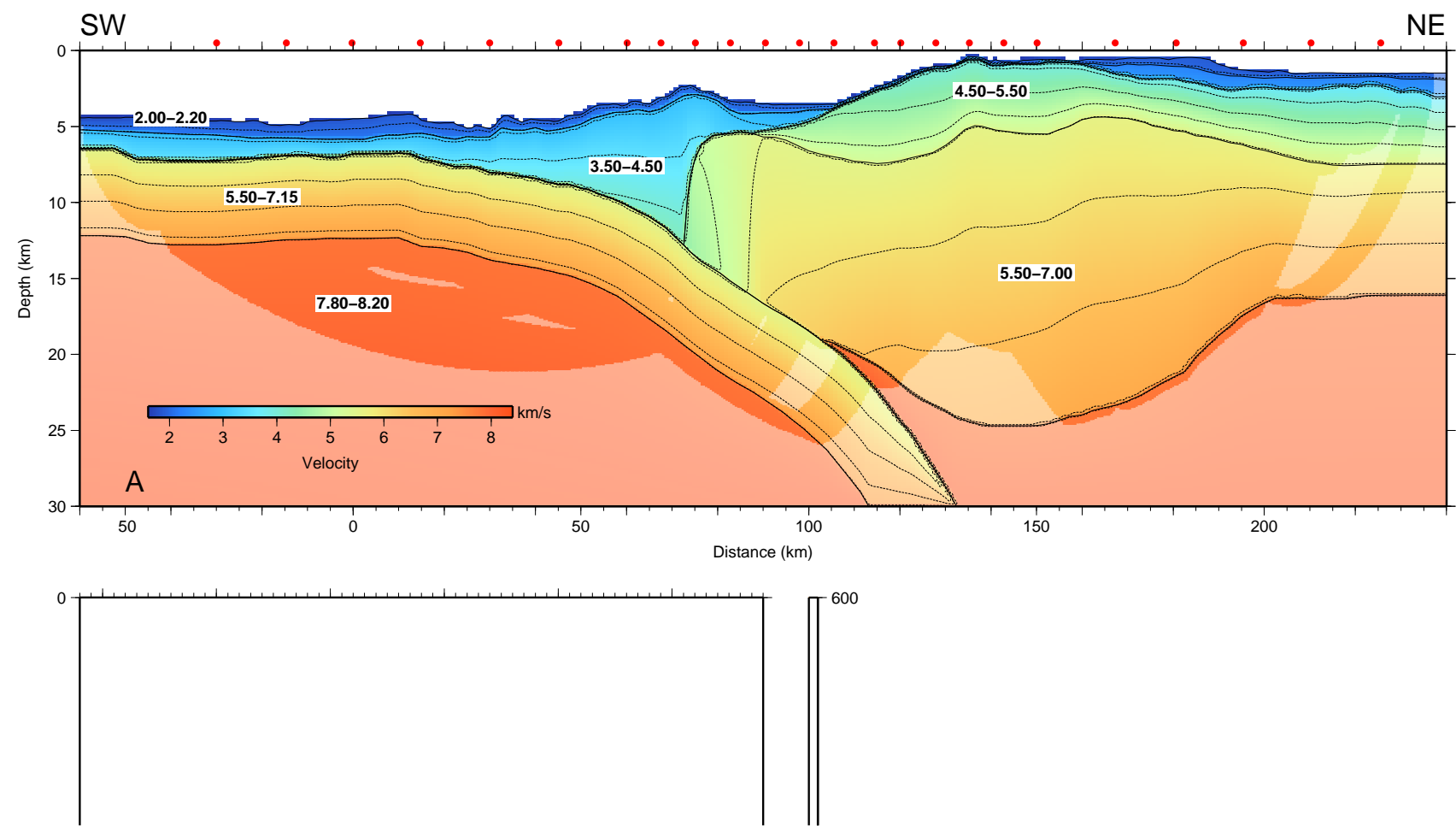

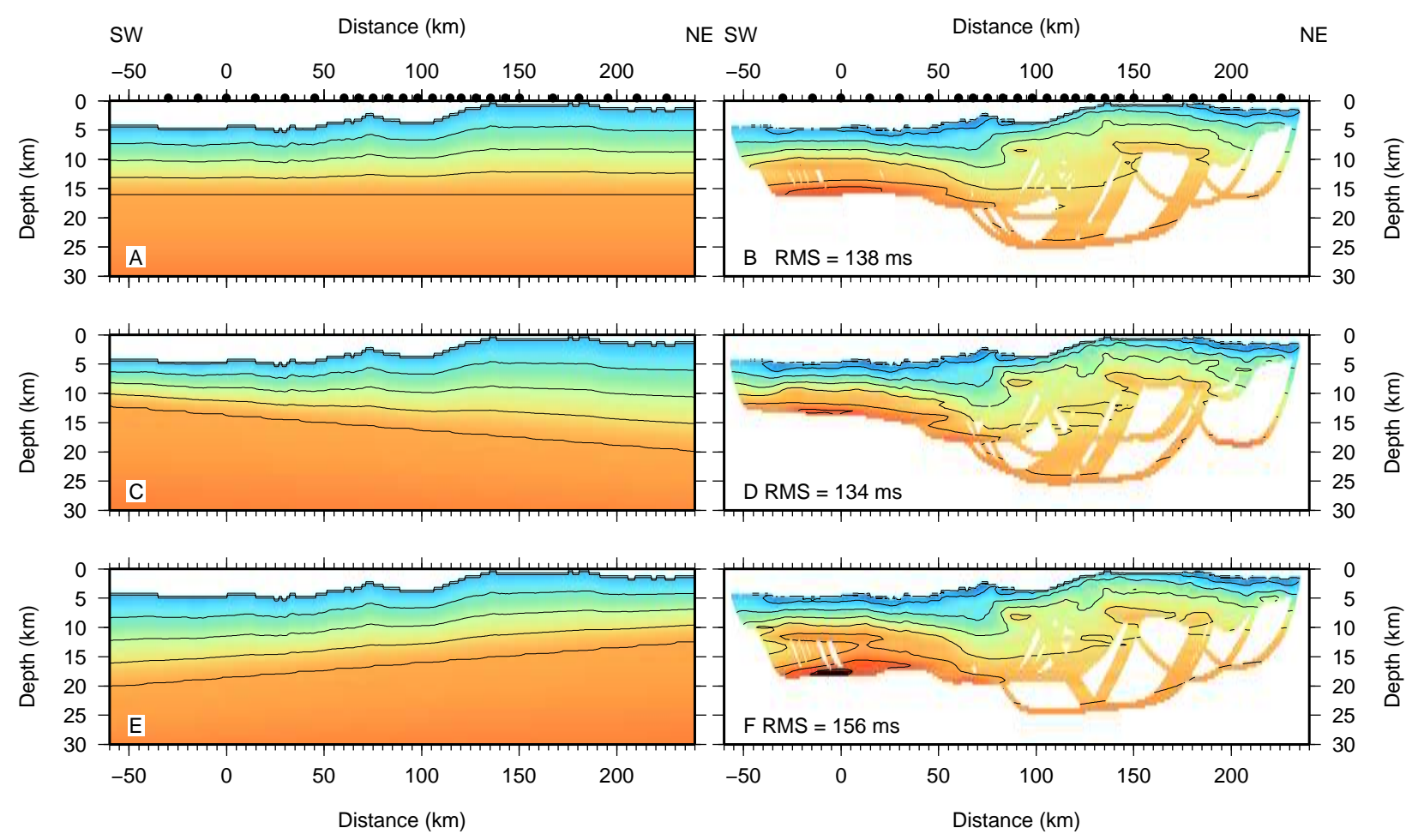

Figure 6. 


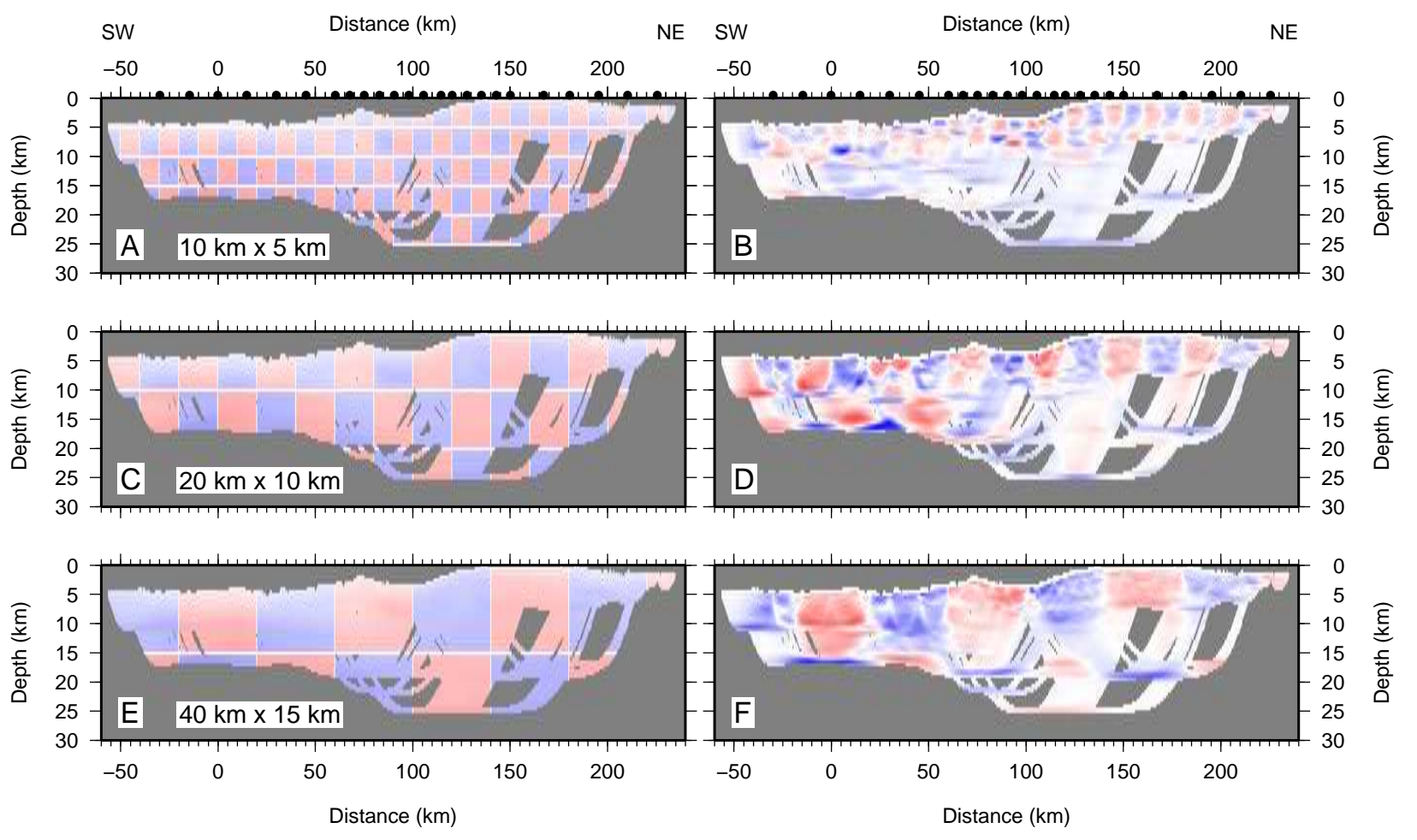

Figure 7. 


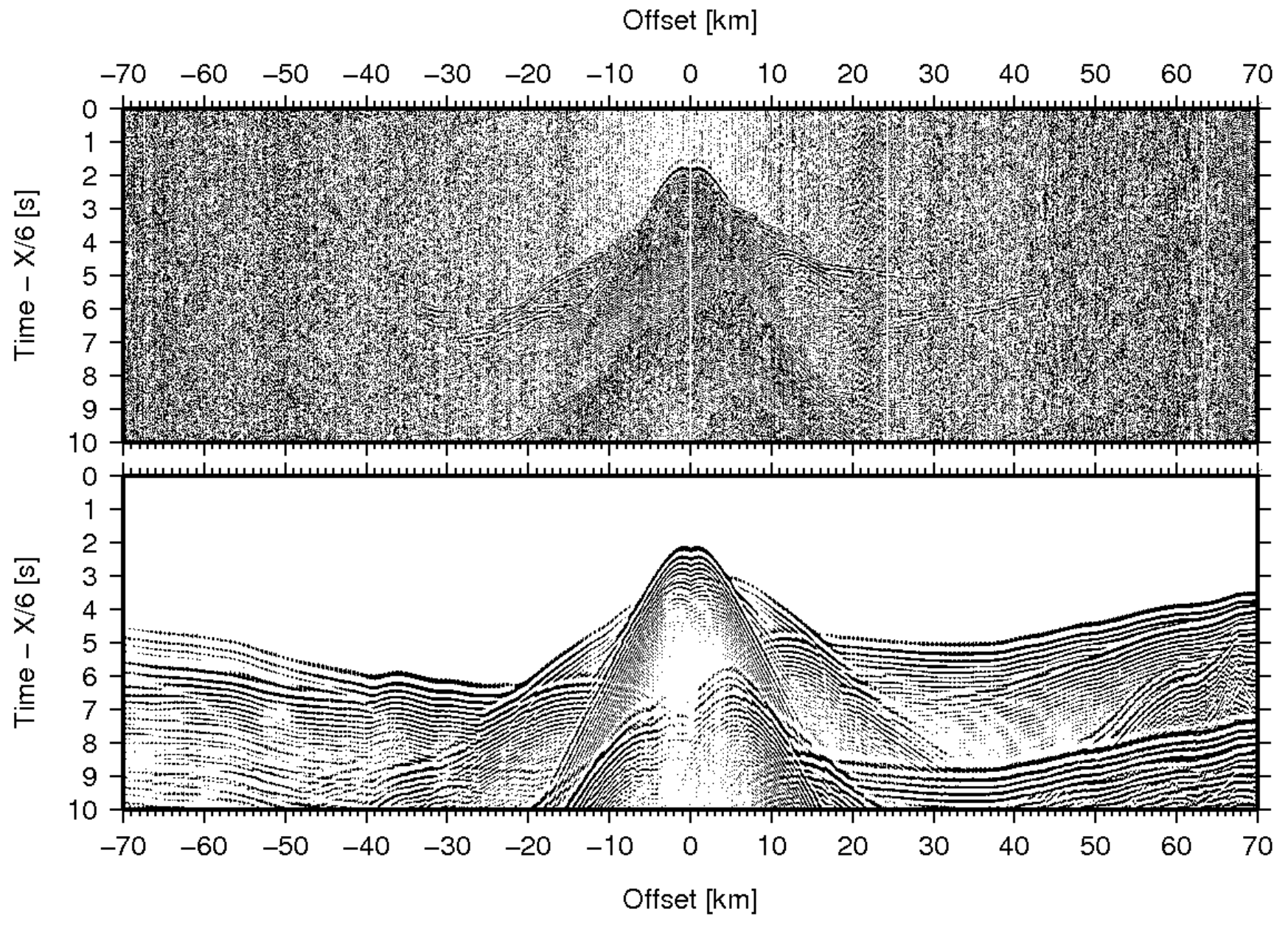

Figure 8. 

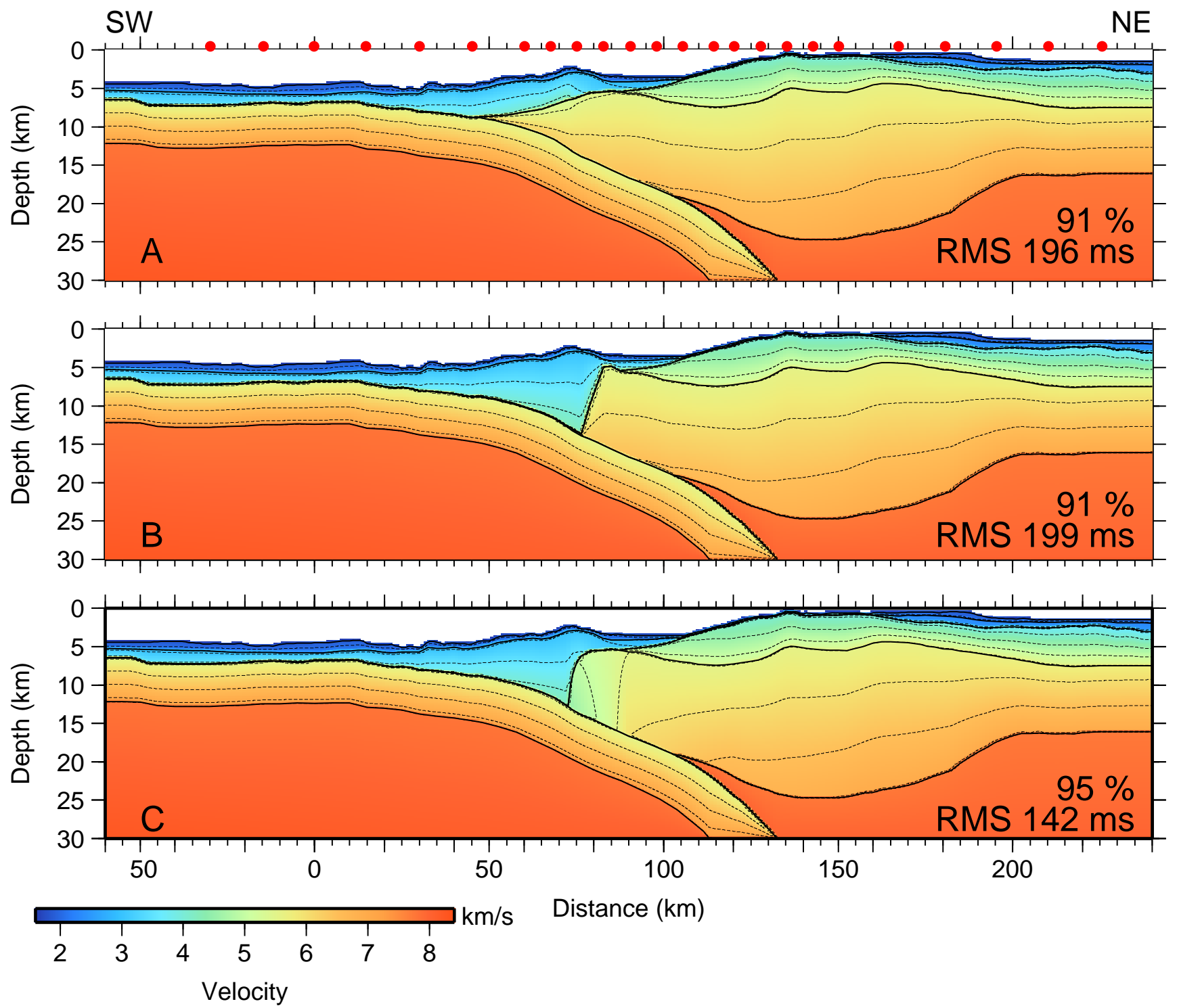

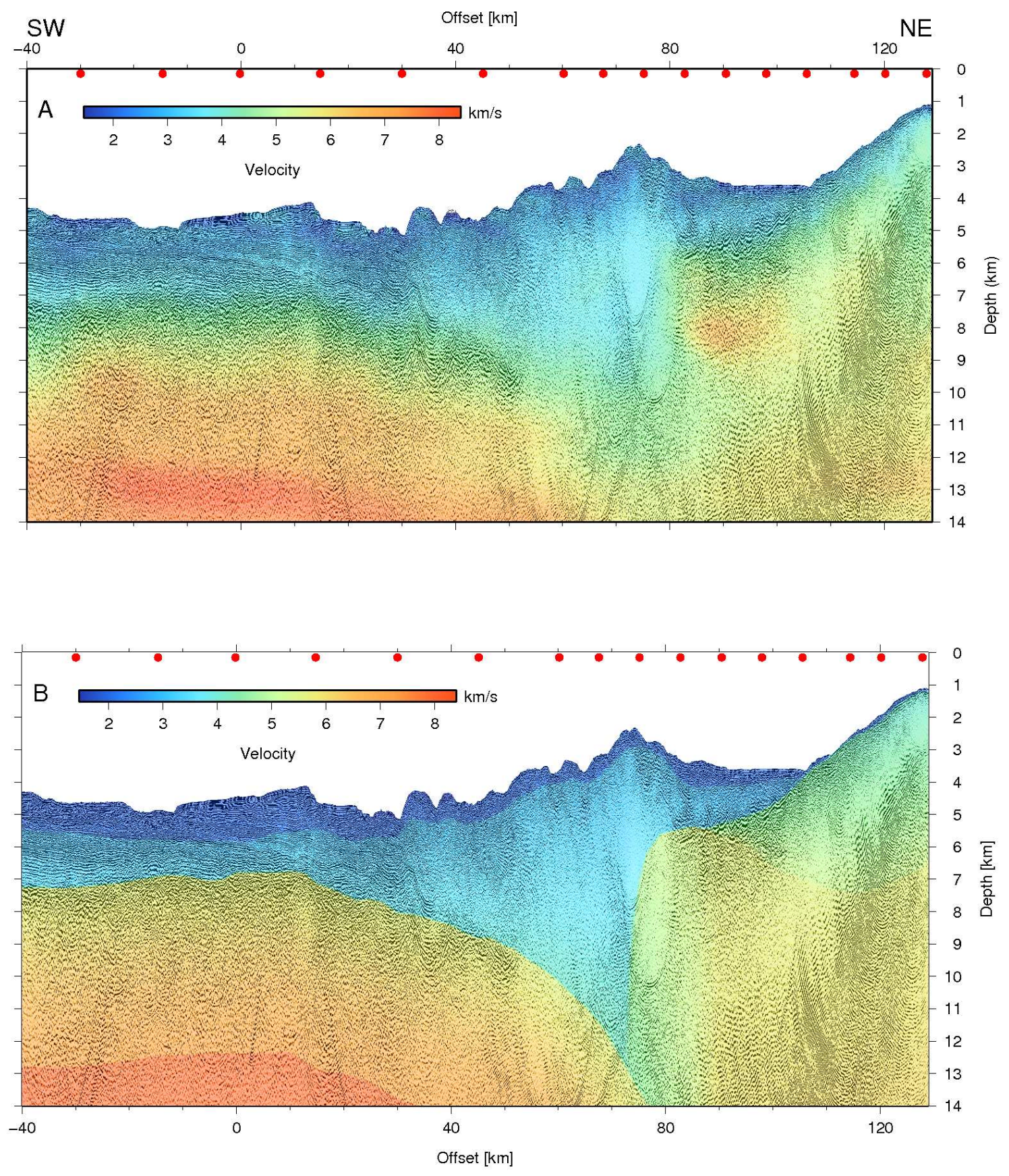

Figure 10. 


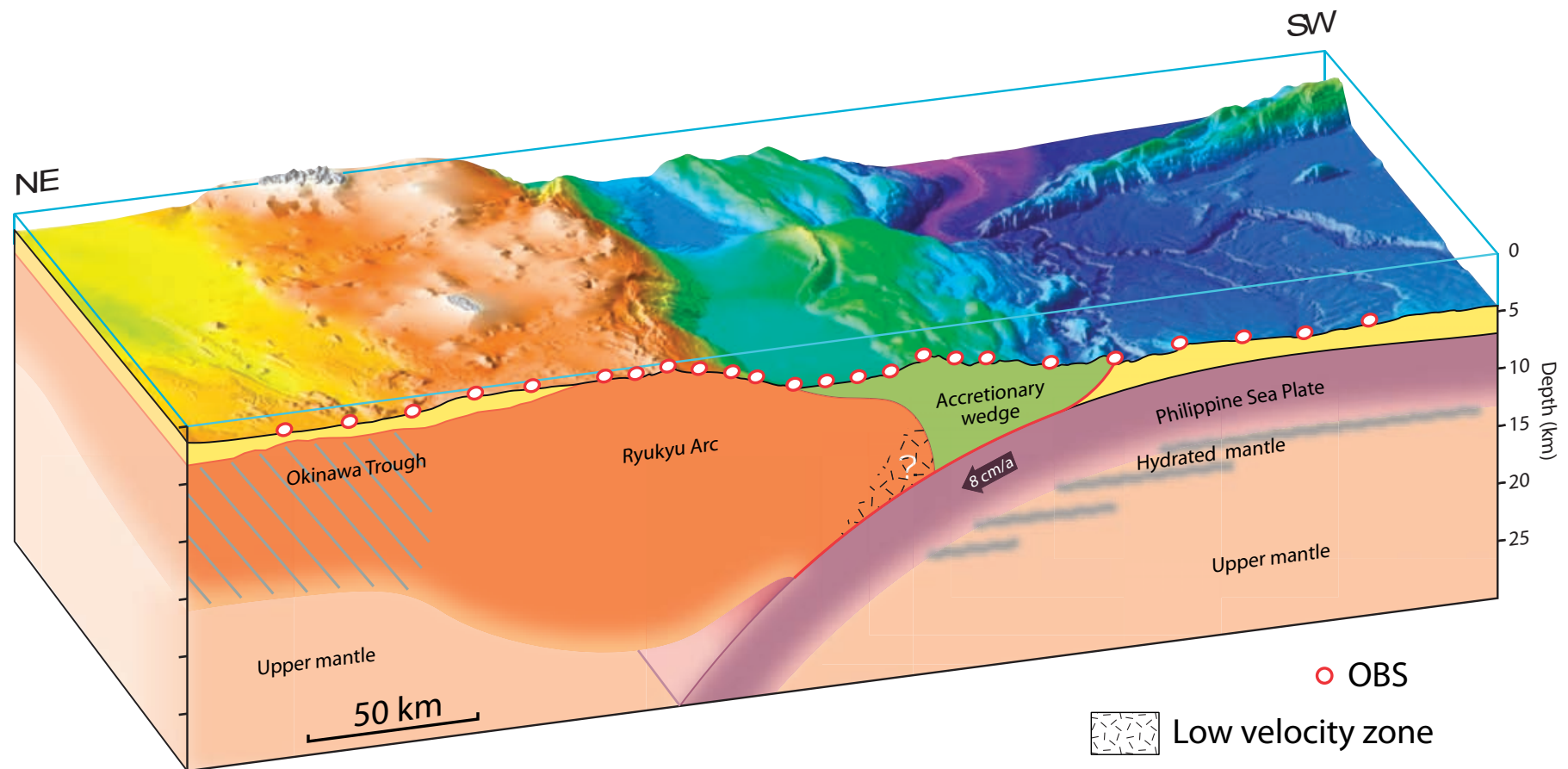

Figure 11. 


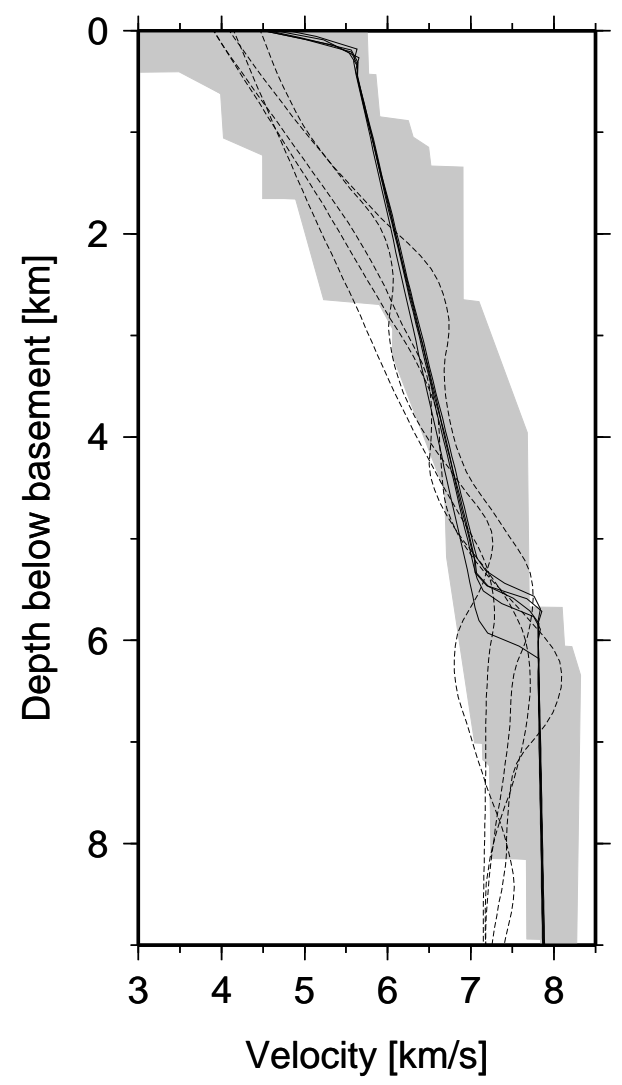

Figure 12. 